\title{
Sex and Gender Equality Policies in Education in Three Southern European Societies: the cases of Andalusia and Valencian Community (Spain) and Portugal / Las políticas de igualdad sexual y de género en educación en tres sociedades europeas del sur: Ios casos de Andalucía y la Comunidad Valenciana (España) y Portugal
}

\author{
Mar Venegas \\ Department of Sociology, University of Granada, Spain / España \\ mariter@ugr.es \\ Alícia Villar-Aguilés \\ Department of Sociology and Social Anthropology, University of Valencia, Spain / España \\ alicia.villar@uv.es \\ Sofia A. Santos \\ Centre for Educational Research and Intervention, University of Porto, Portugal \\ sofiasantos@fpce.up.pt
}

Recibido / Received: 10/05/2018

Aceptado / Accepted: 18/11/2019

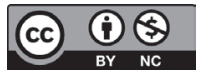

\section{ABSTRACT}

Gender mainstreaming is an international strategy in Europe relating to gender equality using an intersectional approach. It deals, specifically, with new challenges for sexuality and diversity in education. From within this context, this paper focuses on two goals. The first is to analyse sex and gender equality policies in education, since the 2000s, in three Southern European societies: Andalusia and Valencian Community, in Spain, and Portugal. The second goal is to arrive at some comparative conclusions about the recent developments in sex and gender equality policies in education in these three societies. We end with some comparative conclusions. First, there is the political orientation of governments, which seems to be of relevance. Second, there are the policies and plans reviewed, which show a move from (binary) gender equality to a more inclusive gender equality that intersects with sexuality and diversity. Sexuality education, already available in Portugal, is still absent from Spanish schools. These three experiences can inform European public policies.

Keywords: gender policy; sexual policy; equality; sexuality education; diversity.

\section{RESUMEN}

La incorporación de la perspectiva de género es una estrategia internacional en Europa hacia la igualdad de género, que aborda nuevos retos relativos a la sexualidad y la diversidad en educación, desde un enfoque interseccional. En este contexto, este artículo se propone dos objetivos. Primero, analizar las políticas de igualdad sexual y de género en educación desde la década de 2000 en tres sociedades del sur de Europa: Andalucía y la Comunidad Valenciana, en España y Portugal; en segundo lugar, llegar a algunas conclusiones comparativas sobre los desarrollos recientes en las políticas de igualdad sexual y de género en educación en estas tres sociedades. El artículo se cierra con algunas conclusiones comparativas. Primero, la orientación política del gobierno parece ser relevante. En segundo lugar, las políticas y los planes revisados muestran un cambio de la igualdad de género (binaria) a una igualdad de género más inclusiva que intersecciona con sexualidad y diversidad. La educación para la sexualidad, incorporada ya en Portugal, está todavía ausente en la escuela española. Estas tres experiencias pueden ser de utilidad para las políticas públicas europeas.

Palabras clave: política de género; política sexual; igualdad; educación para la sexualidad; diversidad.

\footnotetext{
*Autor para correspondencia / Corresponding author: Mar Venegas. mariter@ugr.es.
}

Sugerencia de cita / Suggested citation: Venegas, M., Villar-Aguilés, A., Santos, S. A. (2020). Sex and Gender Equality Policies in Education in Three Southern European Societies: the cases of Andalusia and Valencian Community (Spain) and Portugal. Revista Española de Sociología, 29 (1), 137-151. (Doi: http://dx.doi.org/10.22325/fes/res.2020.09) 


\section{INTRODUCTION}

Gender mainstreaming is an international strategy in Europe aimed at accomplishing gender equality (see the EIGE) ${ }^{1}$ and dealing with new challenges regarding diversity (Duru-Bellat, 2011) and sexuality in education (Cruells and Coll-Planas, 2013; Venegas, 2018a), from an intersectional approach (Verloo, 2006; Lombardo and Verloo, 2009; Carbin and Edenheim, 2013). Southern European societies, such as Spain and Portugal, are making an impressive effort in helping the European Union to act against neo-conservative emerging antigender campaigns (Kuhar and Paternotte, 2017) by emphasising the importance of bottom-up experiences (Bustelo, 2016). Within this context, education emerges as one of the most effective means of implementing sex and gender equality policies (Santos, 2015; Venegas et al., 2018), although each country has followed different paths towards their implementation.

In the case of Spain, gender equality policies in education have had a long trajectory, since the 1980s, around the so-called notion of coeducation, or education for equality between men and women (Subirats et al., 2013), within which sexuality education has emerged as a more recent issue (WHO22, 2010; Venegas, 2011; Beaumont and Maguire, 2013; Venegas, 2013a; Venegas, 2018a). On the other hand, in the case of Portugal, concerns with gender equality policies have increased in the last years. Currently, the political agenda is mainly focused on tackling the wage gap and abuses against women, such as, the huge cases of domestic violence, human trafficking and discrimination. Within national equality programmes and strategies, school education emerges as a crucial factor in generating changes and providing gender and sexual equality. Since 2017, the Government challenged the educational system, from pre-school to upper secondary education to implement modules of sex education and gender equality under the compulsory subject of Citizenship and Development. In this paper, we briefly pinpoint the integration of sex education in school curricula at

1 The EIGE is available at: https://eige.europa.eu.

2 WHO: World Health Organization. a national level, since it is designed and monitored by the central government (Santos, 2015; Fonseca and Santos, 2015).

Therefore, the administrative and territorial structure of each country deserves some preliminary consideration. Spain is divided into 17 autonomous communities, including Andalusia and Valencian Community, which have competences in education within the more general directives from the State Ministry of Education, but also under the more global directives from the European Union. This is why it is of interest to analyse these three territorial and administrative levels in Spain ${ }^{3}$. Nevertheless, in Portugal, the central government sets the national directives taking account of those of the European Union. Thereby, it is worthwhile comparing the current regional developments in Spain, such as those in Andalusia and the Valencian Community, with the more global and national situation in Portugal, in so far as, in education, Spanish regional governments are more important, and have more competences, than the national government (Ortbals, 2008; Bustelo, 2016). The reason to study Andalusia and the Valencian Community is rooted in the political orientation of their respective governments in the last decade, socialist in Andalusia and conservative in the Valencian Community4.

Taking account of these considerations, this paper aims: 1) to analyse sex and gender equality policies in education since the 2000s in three Southern European societies. They are the Spanish regions of Andalusia and the Valencian Community, and Portugal. In so doing 2) to arrive at some comparative conclusions about the recent developments in sex and gender equality policies in education in these three Southern European societies.

The paper starts by presenting a brief review of the European Union's directives, which regulate (to improve) sex and gender equality policies in education, which comprise sexuality education policies in school settings. Then, we analyse the milestones

3 To learn more about the regional division of subnational governments, multi-government Spain, see Ortbals (2008) and Bustelo (2016).

4 To learn more about the importance of the political party in office in each Spanish region for the development of gender equality policies, see Ortbals (2008) and Bustelo (2016). 
regarding this field in both countries. Following this, we conduct a regional analysis relating to Spanish regions of Andalusia and Valencian Community. We conclude this paper with a reflection on the comparative analysis of these three cases of interest for the current policies on sex and gender equality in Southern European societies.

\section{A SOCIOLOGICAL FRAMEWORK IN ORDER TO ANALYSE SEX AND GENDER EQUALITY POLICIES IN EUROPE}

In this section, we delimit the sociological structure on which we base our approach to the key topics and ideas that define sex and gender equality policies in education.

In times when, as the last European Union citizenship report (2017) emphasises, we are still confronted with sexual abuses and gender violence, and inequality and discrimination at several levels, it makes sense to recover the principles of citizenship and sexual citizenship in order to analyse sex and gender equality policies in education (Santos, 2018). Feminist movements have been crucial in identifying the gendered, ethicised, racialised, classed process (Venegas, 2018b) from which someone was able to be a citizen. They have also highlighted how women have been relegated as Others or the "second sex" by male privilege (Beauvoir, 1949). They were fundamental in the questioning of these gender-blind policies and the universality in which dominant discourses of equality and rights were based (Young, 1997; Arnot, 2003). Therefore, claims for cultural rights emerged in order to highlight the right to participate and be represented in the popular culture, in which education has played important role. These discussions have challenged the neoliberal model of equality as determined by formal heterosexist patriarchal principles and rejected its "false universalism" and the "gender neutral" (Lister, 2004).

Along with this fight for public space, the abuses within the private space, mainly regarding sexuality, could not remain invisible. The need to extent the rights, duties and protection of citizenship to sexual issues and to recognise sexual differences and sexuality free from coercion, abuses and violence became imperative. However, bringing notions of sexuality to the citizenship field is, to begin with, an apparent contradiction in terms (Weeks, 1998; Richardson, 2001; Plummer, 2003). While sexuality was seen as private, the concept of citizenship was traditionally located in the political and public spheres. Thus, sexual citizenship becomes a public strategy more than an academic concept which provides a set of accesses and resources of sexual rights as recommended by international equality plans. Concerning education, these claims are at the foundations of a more open, equal and fair system of sexuality education (Santos et al., 2012).

Moreover, concerns about diversity, which are defined by the European Institute for Gender Equality as "the differences in the values, attitudes, cultural perspective, beliefs, ethnic background, sexual orientation, gender identity, skills, knowledge and life experiences of each individual in any group of people" (EIGE, 2018c: n/p), must be recognised in school education as well (Perry, 2009). Intersecting inequalities such as gender, class, race (Venegas, 2018b), sexual orientation, disability is key for a plural educational environment concerned with inclusion and democracy (Richardson and Monro, 2012).

This brief sociological approach forms the theoretical basis that frames our analysis of sex and gender equality policies in education in the three Southern European societies which we analyse below. Before so doing, a brief review of the European Union's main directives is presented in the following section.

\section{GENDER AND SEXUALITY IN EDUCATION POLICIES IN THE EUROPEAN UNION}

Gender Equality Policies were introduced in 1957 for the first time in Europe (Jacquot, 2016). The first equality actions of the European Economic Community (EEC), such as equal pay for male and female workers, were economic in nature. Art. 119 (art. 157 of the Treaty on the Functioning of the EU) was the unique policy in European gender equality until 1997. This article, which was quite productive, made the European Union one of the most progres- 
sive political systems worldwide. It also became the most solid pillar of the Social Europe.

Since 2011, gender equality has been included in the justice portfolio, as part of a broad policy of fundamental rights. Nonetheless, Jacqout (2016) states that, nowadays, "the European policy of gender equality is threatened with dismantling, and even with gradual extinction" (n/p). We might guess that, to some extent, it has to do with emerging anti-gender campaigns in Europe (Kuhar and Paternotte, 2017), which coincide with the effect of the economic crisis and the conservative turn of European politics (Bustelo, 2016).

Among all the policy areas for gender mainstreaming in the European Union, education is one of the most important insofar as it is a key factor for social change relating to equality, the defence of human rights and a holistic notion of development (see the EIGE) ${ }^{5}$. Education is also crucial in improving citizenship. The lack of training leaves women at greater risk of social exclusion. Among the main issues in this policy area, we highlight the most important for the purposes of this paper. These include gender prejudices and stereotypes, which must be tackled from within formal education in order to help diminish gender imbalances in society, and gender-related violence and sexism, which are also at the core of sexuality policies in the European Union. The EIGE underlines some key topics within gender-related violence in schools, such as verbal or sexual harassment, sexual abuse, corporal punishment, stalking, cyber-harassment and bullying. According to the EIGE, these practices might make the girls who suffer from them experience school problems such absenteeism, poor performance, school dropout, low self-esteem, depression, pregnancy and sexually transmitted infections (STI) like HIV. The EIGE adds that, although these sexual and gender problems exist in society in general, they are particularly serious in schools and

5 "The European Institute for Gender Equality (EIGE) is an autonomous body of the European Union, established to contribute to and strengthen the promotion of gender equality, including gender mainstreaming in all EU policies and the resulting national policies, and the fight against discrimination based on sex, as well as to raise EU citizens' awareness of gender equality" (https://eige. europa.eu/about-eige). in adolescent years. Some studies ${ }^{6}$ show that, even when the incidence of these problems is higher in girls, boys are also at risk. This is because they can experience discrimination, bullying and violence, due mainly to their sexual orientation, disability or ethnicity. In relation to bullying, it is often gendered and it reflects and imbalance of power relations. Not fitting the gender norms is another frequent reason of suffering from bullying.

This is how equality policies gradually move from gender to gendered sexuality issues in education (Venegas, 2018a). Subsequently, sexuality policies in education arise as the most appropriate mechanism to tackle all these issues within school settings (Venegas, 2013c; Santos, 2018), as shown below.

\section{Sexuality education policies in the European Union}

Policies for sexuality education in the European Union are contained within Gender Equality Policies, addressing the following main goal:

Disseminating general and technical information, facts and issues which create awareness and provide young people with the essential knowledge and training in communication and decision making skills they need to determine and enjoy sexuality both physically and emotionally, individually as well as in relationships [The Safe Project (IPPF European Network) in 2007, cited in Beaumont and Maguire, 2013: 7].

It should include physiological and relational aspects of sexuality from an open-minded perspective. The key actors are Ministries of Health and Education, family planning associations, NGO, teachers, parents and professionals (in health care, social work, etc.). The European Union, as a whole, does not have policy-making competencies in this field. These belong to each individual member states. Nevertheless, concrete recommendations have been made by several international agencies. According to the briefing

6 See EIGE in: https://eige.europa.eu/gender-mainstreaming/policy-areas/education. 
by Beaumont and Maguire (2013), "Southern European States [such as the ones in this paper, Spain and Portugal] have deficient or inexistent sexuality education programmes [...]. In Spain, the subject is hardly ever taught in schools in rural areas. Overall, the best practises are observed in Benelux, Nordic countries, France and Germany" (p. 8). According to this briefing, Portugal, Spain (and France) are the countries with the highest level of HIV/AIDS. STI infections are higher in the UK, Slovakia, and Spain. Differences between countries can be explained in terms of cultural, religious and economic factors. Beaumont and Maguire (2013) add that it is noticeable that the sexuality educations in Latvia, Cyprus, Estonia and Slovakia are improving progressively more than in Ireland, Spain or the United Kingdom. A similar conclusion was reached by Parker, Wellings and Lazarus (2009) some years earlier, when they concluded that, in Spain, there is no formal curriculum aimed at sexuality education within the education system (Venegas, 2013c). The situation is still the same. On the other hand, in Portugal (as will be described in the following section), they are currently implementing systematic sexuality education resources aimed at all school levels (from pre-school to upper secondary education) within citizenship education lessons.

Beaumont and Maguire (2013) find it problematic that the dominant approach in sexuality education policies emphasises prevention (teenage pregnancy, STI) over educating children on how to live sexuality with pleasure and responsibility. So the focus is more on health than on education itself (Venegas, 2011). It becomes clear in sentences like this: "Sexuality education provides children, teenagers and young adults information about sexuality also with the aim to be protected from a risky behaviour and bad consequences" (Beaumont and Maguire, 2013: 10). In a different sense, a relevant contribution of sexuality is that, according to experts, "where sexuality education is of a higher quality and with efficient content, the level of HIV infection is lower, teenage pregnancy is rarer and gender equality is more respected" (ibid.). This is the role education plays in promoting sex and gender equality, thereby the reason to call for sexuality education in school settings. Additionally, the CEDAW ${ }^{7}$ stresses that the delivery of sexuality education must be free from discrimination and stereotypes and must convey values relating to gender equality.

On the other hand, the Council of Europe considers sexuality education as one of the factors that influence social, mental and physical health and well-being. It is part of human rights education, education for democratic citizenship and intercultural education (see also Venegas, 2013b). The "Pestalozzi Programme" of the Council of Europe aims to avoid prejudice and stereotyping of sex and sexuality. This programme recommends healthy discourse, understanding and respect for sexual diversity, avoiding taboos, violence and discrimination (CE, 2013: n/p).

\section{Some key data to illustrate these issues}

Sex and gender equality in the European Union deals with some of the key challenges and dilemmas which we face nowadays. Sociological data points to those challenges that should be addressed from sexuality education within the context of sex and gender equality policies in education. The European Commission's Report on Equality (2017) gathers some of these key challenges, which are presented here in relation to Spain and Portugal:

- The gender pay gap in 2015 was 16.3 in the European Union 28, 14.9 in Spain and 17.8 in Portugal.

- The number of women on the boards of the largest publicly listed companies (\%) in 2016 was 23.9 in the UE28, 20.3 in Spain and 14.3 in Portugal.

- Sexual violence (including Rape and Sexual Assault) in 2014 was 2,475 women in Portugal and 9,468 women in Spain.

In a different sense, regarding sexual diversity, the FRA ${ }^{8}$ (2013) survey concludes that many LGBT Europeans hide their identity or avoid cer-

7 Committee on the Elimination of Discrimination against Women.

8 European Union Agency for Fundamental Rights. 
tain locations out of fear. Other people experience discrimination and violence on account of being LGBT, although they do not usually report this to the authorities. The report data will inform the European Union institutions and member states so that they can identify the fundamental rights challenges facing LGBT individuals living in the European Union and Croatia. The report offers a basis for developing European and national legal and policy responses to address the needs of LGBT people, and to protect their fundamental rights. On the other hand, the FRA (2014) survey shows that trans people experience the highest levels of discrimination, harassment and violence among LGBT subgroups.

In the next two sections, we analyse the three cases proposed in this paper. However, first, it is important to remember that, due to their different political, territorial and administrative organisations, the analysis is focused on these three cases according to their competences in education policy making. Therefore, Portugal is analysed as a centralised political unit. However, in Spain, state gender equality policy making is only briefly reviewed, in order to approach a further level of education policy development, which applies to the regions of Andalusia and the Valencian Community.

\section{SEX AND GENDER EQUALITY POLICIES IN PORTUGAL}

\section{Gender equality plans in Portugal}

In Portugal, gender concerns in education are not new. Since 1986, the Lei de Bases do Sistema Educativ ${ }^{9}$ emphasized the need, as a major component of its educational system, "to ensure equal opportunities for both sexes, in particular coeducation practices". Twenty years later, concerns about equal opportunities in relation to the access to pedagogical didactic resources also required school textbooks to comply with the values of nondiscrimination and gender equality ${ }^{10}$.

9 Law $n^{0} 46 / 86$, amended in 2005, and later in 2009.

10 Law $n^{\circ} 47 / 2006$.
Since 2007, the focus on gender education has been supported by three National Equality Plans $(\mathrm{PNI})^{11}$, as a political measure of gender mainstreaming to meet CEDAW commitments. Each plan lasts for three years and is the responsibility of the CIG - Commission for Citizenship and Gender Equality, which seeks to find an answer to the social and political changes embracing the new paradigm that evolves from women's rights to that of gender equality.

Looking at the National Plans, we see that there has been a shift of focus to non-discrimination and sexual diversity issues. The focus on professional, family and personal life balance (uses of time) and inequalities in parenthood and the labour market (such as, the wage gap) ${ }^{12}$ have switched to current concerns with new masculinities and femininities, gender identity and gender violence ${ }^{13}$. Indeed, in the III Plan (2007-2010) the parity between men and women in the labour market, and in the sexual and reproductive health agenda, was strongly influenced by the abortion law. This was despite the fact that the diversity among women - those more vulnerable such as single mothers, women with disabilities, immigrants - and the elderly were not explicitly considered. The consolidation of new gender roles, the valuing of affection and care appeared as central to active citizenship in Plan IV (2011-2013) and V (2014-2017), as result of public debates and the sanctioning of same sex marriage. It was within this political and social context that the latest law on Sexuality Education ${ }^{14}$ was designed and implemented, in addition to the national guidelines on education, gender and citizenship for all school levels (from primary to secondary education $)^{15}$. Current national plans are detailed in following section.

11 National Plans for Equality are available online at https://www.cig.gov.pt/documentacao-de-referencia/ legislacao/cidadania-e-igualdade-de-genero/.

12 III National Plan for Equality - Citizenship and Gender (2007-2010).

13 IV National Plan for Equality, Gender and Non-discrimination (2011-2013).

14 Law n ${ }^{0} 60 / 2009$, Sex Education at school.

15 V National Plan for Equality, Gender and Non-discrimination (2014-2017). 


\section{Gender and sexuality education in school}

In Portugal, the advances and setbacks in the history of sexuality education have been deeply rooted in gender equality and sexual claims by different political parties and sectors of society.

The presence of gender and sexual equality in the educational field has become more consistent in recent years, mainly under the current left-wing government. Since 2017, two national strategies have been launched, aligned substantively with Agenda 2030 for Sustainable Development, in order to fight structural discrimination in this field: the National Strategy for Citizenship Education (ENEC) and the National Strategy for Equality and Non-Discrimination 2018-2030 "Portugal + Equal" (ENIND). According to Agenda 2030, global and structural action must include the equal participation of women and men in both public and private sectors, including the scientific and technological, and the elimination of all forms of discrimination against sexual orientation and violence. This is mainly supported by other international mechanisms in the field such as the European Pact on Equality between Men and Women 2011-2020, the Strategic Engagement for Gender Equality 20162019; Development Strategy for Gender Equality and women empowerment (CPLP 2017-2020).

ENIND includes three National Action Plans on gender equality for the next four years. The first plan - "Action Plan for Equality between Women and Men", focuses mainly on the Roma community and the promotion of digital skills for women. The second plan aims at fighting "violence against women and domestic violence". The third, fights "discrimination based on sexual orientation and gender identity". According to these axes, this strategy aims to break gender and ethnic inequalities and injustices, and prevent men and women from violence and discrimination, due to the high rates of femicide ${ }^{16}$. Although it is decreasing, in 2017, 20 femicides and 28 femicide attempts were identified (OMA, 2017) and domestic violence (an average of 5036 women and 775 men were victims

16 Femicide or feminicide is a sex-based hate crime, broadly defined as the intentional killing of females, either women or girls, just because they are female. of domestic violence in 2017) (APAV, 2017). In 50\% of the cases, the crime was committed by husbands, partners and boyfriends and in $22 \%$ of cases by ex-husbands, ex-partners, ex-boyfriends. This highlights the need for sexual, but mainly relational and affective education (OMA, 2017). Violence goes beyond the domestic sphere and discrimination now includes gender identity, in addition to sexual orientation. Gender identity and transsexuality has gained ground in the context of public discussion, as a result of the new law on gender identity, approved in April 2018, that allows young adults aged 16 and over to change their name and identity in legal documents.

Therefore, public policies on equality and citizenship share a common view with the motto "No one can be left behind", which implies a collective commitment of all sectors in defining measures.

Within this context, educational institutions and schools emerge as one of the main sites of action. Last academic year (2017-2018), the government implemented the project of autonomy and curricular flexibility from primary to secondary education in line with discourses of educational decentralization. This project covers state and private schools, whose governing bodies and administrations are responsible for the management of the curriculum in a contextualized way (having $25 \%$ of the time of the curricula to decide what to do). Schools are taking a central role.

As part of the new educational reform, concerns relating to violence, discrimination, inequality and injustice in schools came to the fore. The compulsory implementation of the subject: Citizenship and Development Education emerges as a key step to reinvest and reinforce gender equality and sexuality education. Within this strategy, gender equality becomes compulsory at all school levels, while sexuality education is compulsory in some school years, mainly in low secondary education. This political proposal moved sexuality education from health to within a citizenship framework, thus expressing wider concerns with gender identity, discrimination, sexual and women's rights and in line with the latest law of sexuality education.

The implementation of school-based sexuality education in Portugal has been surrounded by a set of political changes and controversies since 1984 
(the first legislation). The first decade of the $21^{\text {st }}$ century was clearly a time of tension and debates that opposed conservative lobbies against new claims for citizenship around: the (contested) law to decriminalise abortion ${ }^{17}$; the approval of samesex marriage ${ }^{18}$ and the moral struggle against the compulsory implementation of sexuality education. These tensions strongly affected sex education and highlights the interdependence between social, political and educational debates

In 2009, the first law solely focused on sexuality education, as an autonomous and compulsory knowledge for curricula, was launched for all grades in both state and private schools. Its greatest innovation was marked by the priority given to new a set of new contents relating to sexuality, affections, sex and relationships education, sexual abuses and other forms of coercion, gender equality and the respect for pluralism. It was addressed in non-disciplinary areas of the curriculum, such as citizenship education, for 12 hours in secondary schools (for pupils from 15 to 18 years old) and a minimum of 6 hours in low-secondary schools (for pupils from 10 to 15 years old). This proposal was weakened, in 2011, by the elimination of these areas from the curriculum, but has now been strengthened by its integration in some National Equality Plans (PNI) and recently in the ENEC.

\section{SEX AND GENDER EQUALITY POLICIES IN SPAIN}

\section{The state level}

The two first decades of the $21^{\text {st }}$ century have been of special significance in terms of gender legislation, approving the most important state and regional laws in terms of gender equality, including gender-related violence. For the aims of this paper the first, and most important, milestone at the state level in Spain is the Organic Law 1/2004 28

17 Law $n^{0} 16 / 2007$ IVG - Voluntary Interruption of Pregnancy. Abortions can be carried out by public health services up to the first 10 weeks of pregnancy, based on a women's own decision.

18 Law n ${ }^{0}$ 9/2010 - Same-sex Marriage. Portugal was the sixth European country to legally enable marriage between homosexual couples.
December, on Comprehensive Protection Measures against Gender Violence ${ }^{19}$. Another state norm is the Organic Law 3/2007, 22 March, for the effective equality of women and men. A third relevant one is the Organic Law 2/2010, 3 March, on sexual and reproductive health and the voluntary interruption of pregnancy, which is a unique law that explicitly emphasises the need to include sexuality education in the Spanish setting and also the 17 regional official curricula in school settings. This law, approved by the socialist party, was abolished when the conservative party won the elections in 2011. Since then, nothing has been done about it.

Explicitly in the educational arena, the LOGSE ${ }^{20}$ (1990) is the landmark, since it is the law that establishes the principles aimed at a coeducational system, specifying that "from the coeducational system of education the real equality of women and men shall be enhanced, in all its dimensions: curricular, school and others" (art. 5.2).

\section{The autonomous community of Andalusia}

Since the 1980s, under socialist governments, Andalusia has been developing a remarkable strand of research and pedagogic materials on gender and equality in the so-called model of "coeducation" (Subirats, 2013), which:

Proposes an education that breaks with the limits imposed by the categories of gender, that breaks with the hierarchies in the relationships between the sexes, that rescues the value of the basic knowledge for the life of feminine cultures and women's knowledge, and that empowers and generates new and richer identities in female and male students (Regional Ministry of Education, 2005: 43).

This significant work has been the result of the close cooperation between the Andalusian Women's

19 Plan I (2005) analysed in the Andalusian case is, in fact, a consequence of this Organic Law regarding its educational directives.

20 Ley Orgánica General del Sistema Educativo (LOGSE), $3^{\text {rd }}$ October, 1990, introduced by a socialist government, replaced the previous general law on education (1970), during Franco's dictatorship. It was the first democratic, egalitarian educational law in Spain. 
Institute and the Regional Ministry in charge of Education (see also Ortbals, 2008). Consequently, Andalusia approved its first plan in 2005, called I Plan of Equality between Men and Women in Education. In 2016, the I/ Strategic Plan of Gender Equality in Education was approved. The change in titles produced a global shift from the binary definition of gender to the recognition of the diversity "of gender identities, sexual orientations and family models", as shown in Plan II (see also, Venegas, 2018a).

Plan I (2005) is based on the significant gender changes in Andalusia and Spain since the 1980s, though it also embraces also the structural challenges for equality yet to be achieved. Plan I focuses on the promotion of a gender equality model synonymous with equality between men and women. Plan II (2016) goes back to the principle of equality in order to review the promotion of democratic citizenship (Venegas, 2013b).

Some key laws, both at state (as indicated above) and regional levels, framed in Plan II (20162021), continue to defend equality in education and add other current dimensions of interest like diversity of gender identities, sexual orientations, family models and forms of coexistence, understanding both men's and women's needs (to adopt the relational, structural approach of gender relations), and rethinking masculinities rather than femininities.

Plan I draws on three principals. They are visibility, transversality and inclusion (this is being different from diverse, but not unequal). Plan II adds a forth principal: parity. Plan I aimed four main objectives; each one was specified in a series of special actions, the most relevant ones (in relation to the objectives of this paper) are presented below.

Objective 1 tries to facilitate the understanding of the differences existing between women and men. Some key measures are: the introduction of a coeducational module in initial teacher training, the secondary elective subject called "Social Changes and Gender"21, and the preparation of good practice guides aimed at changes in gender relations in schools. Sexuality education is not in-

21 See Didactic Guide in http://www.juntadeandalucia.es/educacion/portalaverroes/documents/ 10306/1513789/guia_didactica.pdf. cluded as such anywhere in Plan I, but this elective subject includes Chapter 4, dedicated to "Relations and Feelings". This is the official curriculum which is closest to this topic, and it is absent from the Spanish curriculum throughout the rest of the country (Parker et al., 2009; Beaumont and Maguire, 2013).

Objective 2 aims to promote equal educational practices. Here the key measures are to promote a non-sexist, non-androcentric model in all aspects of the education system, and to appoint a teacher responsible for coeducation in each school financed with public funds. The latter shows another key novel aspect for equality in education in Andalusia.

Objective 3 is to promote changes in gender relations, following some relevant measures such as training in care work, to make the contributions of women in history visible in the curriculum and, again, the elective subject mentioned above. In this sense, the remarkable Equality Plan Collection ${ }^{22}$, created by the Regional Ministry of Education, together with the Andalusia Women's Institute, to give support for the implementation of Plan I, offers materials to help the educational community to work on these issues. 0bjective 3 includes the issue of funding coeducation projects together with parents' school-based associations.

Finally, objective 4 aims to correct the imbalance of responsibilities among teaching staff. In so doing, it proposes to promote the participation of teachers in the management bodies of the Regional Ministry of Education, and to include data disaggregated by sex in the evaluation of teacher activities.

Between the two plans, a regionally relevant norm was approved: the Law 2/2014, 8 July, integral for non-discrimination on grounds of gender identity and the recognition of the rights of transsexual people in Andalusia. For the first time in Andalusia, trans people's rights were recognised and defended.

Plan II, due to its strategic nature, offers a different, more complex model based on 4 strategic lines, detailed in 4 objectives, from which 11 mea-

22 See all documents and the whole Collection in http:// www.juntadeandalucia.es/educacion/webportal/web/ portal-de-igualdad/coleccion-plan-de-igualdad. 
sures are stated in addition to a total of 69 actions. Each action is detailed with particular indicators to make the implementation evaluable. Only the most relevant actions are analysed here. They illustrate the shift of paradigm previously mentioned.

Line 1 refers to a School Plan with a gender perspective, so the purpose of objective 1 is to establish the best conditions needed for schools in order to implement coeducation plans through no-gender bias organization and their curriculum. Some actions to be highlighted are the inclusion of a Gender Equality Plan within the School Plan including equality, coeducation and prevention of gender violence, discrimination, harassment or sexist behaviour based on the idea of inferiority or superiority of any sexual orientation, or in the expression of a gender identity different from that assigned at birth. This action is a good example of the paradigm shift defended in this paper. Another key action here is gender mainstreaming in didactic programming, making women's contribution, and their struggle for citizenship rights, visible. The elective subject "Social Changes and Gender" is kept on.

Line 2 focuses on sensitization, training and involvement of the educational community, so objective 2 is to implement actions in this sense in relation to gender equality, coeducation, and prevention of gender violence. A remarkable action here is long-life teacher training in matters of gender equality and the prevention and eradication of gender violence, including the elimination of discrimination based on either inferiority or superiority of any sexual orientation or expression of gender identity. Another is to include materials to show diversity of gender identities, sexual orientations, models of families and living together, to avoid discrimination on those grounds.

Line 3 is to contribute to the eradication of gender violence, so objective 3 is to promote actions to raise awareness and prevent gender-based violence, to eradicate it, and to intervene possible cases properly. A remarkable action appeals to the absent factor in sexuality education: the care of egalitarian socialization and emotional education at all educational levels, with special attention paid to the value of affection and love in young people's relationships. Another action refers to edu- cation in non-sexist values, deconstruction of gender roles, and sexuality education taking account of the different recognized sexual orientations, personal autonomy, construction of self-concept and development of a life project without gender biases, emotional education, adequate conflict management and prevention of gender violence. It is also to make both students and families aware of the safe use of information and communication technologies, to avoid identity theft, cyber bullying, grooming, sexting or different ways of exercising gender violence through them. In addition, it aims, in schools with socially vulnerable students, to educate families in ways of avoiding practices such as arranged marriages or female genital mutilation which violate the freedom, health and integrity of girls and young people. Furthermore, it promotes the need to detect gender violence in education, including harassment or sexual abuse through social networks and all types of sexist, homophobic or transphobic attacks. Finally, it aims to implement an action protocol on gender identity in the Andalusia education system. Line 3 explicitly gives account of the emphasis Plan II sets on sexuality, diversity and equality.

Line 4 refers to the structural measures in the education system itself, so objective 4 is to promote the integration of the gender perspective in the functioning of the educational administration in general. An exceptional initiative is to promote cooperation with universities aimed at training teachers in all these sex and gender equality issues.

We end this section with some more evidence. Plan II was designed over the evaluation of Plan I. It concludes, "The autonomous community of Andalusia has been a pioneer in the development of an equality plan in education" (AGAEVE, 2014: 55). The main contribution of Plan I has been to establish awareness of gender equality in the education community. Teachers and staff in charge of Plan I highlight key aspects such as a more adequate treatment of gender equality, a more inclusive use of language; data disaggregated by sex, better coexistence and more equal treatment, more interest in coeducation; the search for gender equality; students' awareness and parental participation. Plan I stated the basis for Plan II, which searches for carrying equality further until 2021. 


\section{The Valencian Community}

In the case of Valencian Community, we refer to two clearly differentiated political periods. The first, which started in 2003, is when the Valencian Government approved the General Act on Equality between Women and Men. This lasted until 2015, when a new political period, marked by the political change of the Valencian government began after 20 years of the Partido Popular government (right wing). A new government was formed (left wing) by the pact of Partido Socialista del País Valencià (PSPV), Compromís and Podem. It brought about a significant political change.

The approval, in 2003, of the Valencian Act on Equality marks the beginning of political actions in this area, and one of the first Spanish laws on this matter, which came even before the state Act in 2007. However, there was a lot of criticism from various social and political sectors because it was not fully developed. In this first period, there had not been a specific plan relating to equality in education, so it was not a priority for the $\mathrm{Va}$ lencian conservative Government, though the 2003 Act devotes some articles to education for equality, drawing on the LOGSE (1990). However, the annual coeducation plans proposed by this law were never carried out. According to the Legal Advisory Council, this law proclaimed goodwill principles, but did not always establish the means to achieve them.

In 2010, the Valencian Community approved an order to regulate a work-family balance seal in the business field, which was a priority in the equality policy implemented in the first political period, during which liberal policies were prioritised. It has dominated the vision of equality, prioritising actions in the field, such as the creation of the seal "Fent Empresa. Iguals en Oportunitats" ("Doing business. Equal in opportunities").

In the first period, two initiatives on equality in the Valencian Community were approved: the plan of the Valencian Government to combat violence against women (2010-2013) and the plan for Equal Opportunities for Women and Men (2011-2014). The first is a specific plan focused on violence against women, so it cannot be considered a global equality plan. The second, approved in the last term of Partido Popular in Valencian office, can be considered an equality plan, highlighting the idea of equal opportunities.

Despite this, in the last two years the Valencian Community has witnessed an accelerated change in policy making on equality and education, linked to social welfare actions.

The second political period started with the May 2015 political change. The new three-party Valencian government placed "rescuing people" at the centre of its policies with a gender violence action plan as one of its most outstanding political issues. The agreement refers to the action on gender violence as a mainstreaming objective.

The three-party political agreement incorporates equality perceived as equality in gender identity, specifically through the commitment to approve a comprehensive Law for the effective equality of $\mathrm{LGTB}^{23}$ people. This commitment was fulfilled with the approval of Law 8/2017, of April 7, of the Valencian Government, by recognising the right to identity and gender expression in the Valencian Community. This law defines gender identity as the:

Internal and individual experience of gender as each person feels it deeply, including the personal experience of the body and others such as dress, way of speaking and expressing oneself. Gender identity is generally accompanied by the desire to live and receive acceptance as a member of this gender and even the unwavering desire to modify, by hormonal methods, surgical or otherwise, the body itself to make it as consistent as possible with the gender felt as own when it is not correlated with the one assigned at birth (Preamble to the Law).

The Valencian case joins other communities that offer public health care to trans people. Andalusia pioneered these actions. In this way, this law promotes comprehensive medical and social care, in addition to contributing to the "normalisation" of transgender people. Chapter II of the law is specifically dedicated to measures in the field of education. First, it reflects the will to implement actions on gender identity, gender expression, and

23 Lesbians, Gays, Transsexuals, Transgender, Bisexuals, Intersexuals. 
sexual and family diversity in that area. The Valencian Government expressly assumes the obligation to ensure that the "educational system is a respectful space, free of all pressure, aggression or discrimination on grounds of gender identity, gender expression, sexual and family diversity in any of its aspects or manifestations and will develop measures for the effectiveness of these principles" (article 21). The law states that both the School Project and the curricula must overcome all types of discrimination and the management team must attend and support trans people who belong to the educational community.

This political commitment has been created together with social entities and activists. The result is socially unquestionable. It involves a relevant sociological change making visible to traditionally invisible sexual and gender groups. The transgender category functions as a concept that refers to the move beyond the pathologising, binarist and reifier definitions of the masculine and feminine categories.

Another key milestone in the Valencian Community is the recent approval of the so-called Coeducation Plan in March 2018, in which a large number of social and educational agents participated. It is based on six principles: mainstreaming, visibility, inclusion, intersectionality, equilibrium in parity and democratic values. The plan was recently submitted and, unlike the gender identity law, it does include the mention of equality, as perceived as equality between women and men, understanding coeducation as a tool key to achieve equity and equal opportunities between women and men. We see that here the notion of equity is limited to that of equality as if they were synonymous when in fact they have different scopes. A critique in terms of meritocracy has been allocated to the idea of equity. The plan also includes the objective to address gender identity, gender expression and sexual and family diversity.

It should be noted that the Gender Identity Law (known as the Trans Law), and the Coeeducation Plan, have coincided temporarily in their development. In fact, in the first version of the plan, the dimension of gender identity was not incorporated as a defining characteristic. However, it has been included in its final version, probably due to the influ- ence of the Trans Law, and because the social and political debate was being undertaken at that time.

The Coeducation Plan includes an extensive concept of coeducation, which overcomes the sex in which students have been socialised. Students' deficiencies should be balanced in accordance with the sexism that permeates society. Coeducation includes all sorts of social inequalities and forms of discrimination (sex, gender identity, gender expression, ethnicity, sexual diversity, family diversity, sexual characteristics, origin or social class). This global definition incorporates the intersectional approach and creates a framework that is not just reduced to an idea of coeducation which is understood mainly as an educational model based on gender equality. This is because a coeducational school is inclusive in a broad sense, that is inclusive in diversity, and this presents the challenge of promoting a new cultural model (Villar-Aguilés, 2018).

This intersectional definition also means recognising multi-dimensional inequality in school and the need to address it. In this sense, we draw on the words of Pierre Bourdieu and Jean-Claude Passeron (2003[1964]) when they assert that: "Blindness to social inequalities condemns and authorises to explain all inequalities, particularly regarding educational success, such as natural inequalities, inequalities of talents" (p. 103).

Thereby, this current political term in the Valencian Community represents the move from gender equality - equality between men and womento sex and gender equality - gender diversity of identities and expressions - (Venegas and VillarAguilés, 2018).

\section{CONCLUSION}

In this paper, we have aimed to achieve two main goals. The first one is to analyse sex and gender equality policies in education since the 2000 s in three Southern European societies, which are Andalusia and the Valencian Community, in Spain, and Portugal. Our second goal is, to arrive at some comparative conclusions about the recent developments in sex and gender equality policies in education in these three Southern European societies. The 
global framework for these developments is a European context in which gender first, and sexuality more recently, have become mainstream and linked to the notions of diversity and intersectionality.

After having analysed the three case studies presented in this paper, we conclude with a reflection on the comparative analysis of these cases that might be of interest for current policies on sex and gender equality in Southern European societies. On the one hand, the political orientation of the party in office appears to be important. In the three cases, there is a shared feature: that the further development in sex and gender equality has occurred under left wing governments (see also Ortbals, 2008; Bustelo, 2016).

Though the 1980s saw the beginning of the implementation of gender equality policies in both Spain and Portugal, it is at the turn of century when they increased their visibility and incidence in the educational arena. In our three cases, there is an intertwining of gender and sexuality issues, moving from gender equality to sex and gender equality, even though their rhythms are different. This also involves the implementation of sexuality education within gender equality plans. Nevertheless, Portugal has implemented a proper school-based national sex education policy, while in Spain this matter is not yet present in the school curriculum. However, coeducation has been largely developed in the two Spanish cases described in this paper and some sexuality education issues are covered within it.

Whereas gender equality has not yet been reached, and the high level of gender-related violence is an unfortunate example of this, equality policies are moving towards a more inclusive definition of gender, intersecting sexuality and diversity. The three cases analysed here are good examples of this. Yet, the challenge for Southern European societies, and for the European Union as a whole, is to continue developing these sex and gender equality policies, while, at the same time, bearing in mind the structural dimension that still defines inequality. These concrete Spanish (AndaIusian and Valencian) and Portuguese experiences, together with advances in the commitment to equality, can inform European public policies to go further in this social aim.

\section{BIBLIOGRAPHICAL REFERENCES}

Agencia Andaluza de Evaluación Educativa (AGAEVE) (2014). Estudio sobre evaluación del I Plan de lgualdad entre Hombres y Mujeres en Educación. Sevilla: Junta de Andalucía.

APAV - Associação Portuguesa de Apoio à Vitima (2017). Estatísticas APAV. Relatório anual 2017 (online). https://apav.pt/apav_v3/images/pdf/ Estatisticas_APAV_Relatorio_Anual_2017.pdf, accessed October 31, 2018.

Arnot, M. (2003). Sociologia da pedagogia de Basil Bernstein. Diálogos femininos e elaborações feministas. Educação, Sociedade e Educação, 19, 7-48.

Beaumont, K., Maguire, M. (2013). Policies for Sexuality Education in the European Union. Policy Department C - Citizens' Rights and Constitutional Affairs: European Parliament.

Beauvoir, S. (1949). Le deuxième sexe. Paris: Gallimard.

Bourdieu, P., Passeron, J. C. (2003). Los herederos. Los estudiantes y la cultura. Madrid: Siglo XXI Editores.

Bustelo, M. (2016). Three decades of state feminism and gender equality policies in multigoverned Spain. Sex Roles, 74(3-4), 107-120.

Carbin, M., Edenheim, S. (2013). The intersectional turn in feminist theory: A dream of a common language? European Journal of Women's Studies, 20(3), 233-248.

Consejería de Educación (2005). I Plan de Igualdad entre Hombres y Mujeres en Educación. Colección Plan de Igualdad 1. Sevilla: Junta de Andalucía.

Consejería de Educación (2016). II Plan Estratégico de lgualdad de Género en Educación 20162021. Colección Plan de Igualdad 12. Sevilla: Junta de Andalucía.

Consejería de Educación (2018). Colección Plan de Igualdad (online). http://www.juntadeandalucia.es/educacion/webportal/web/portalde-igualdad/coleccion-plan-de-igualdad, accessed January 17, 2018.

Council of Europe (CE) (2013). Sex/sexuality education - Personal development, prevention of discrimination and violence. Pestalozzi Programme (online). https://www.coe.int/en/web/ pestalozzi/sexed, accessed January 17, 2018. 
Cruells, M., Coll-Planas, G. (2013). Challenging equality policies: The emerging LGBT perspective. European Journal of Women's Studies, 20(2), 122-137.

Duru-Bellat, M. (2011). La diversité: esquisse de critique sociologique. Notes and Documents, 03 , Paris, OSC, Sciences Po/CNRS (online). https:// halshs.archives-ouvertes.fr/halshs-00830016/ document, accessed March 28, 2018.

EIGE (European Institute for GenderEquality) (2018c). Definition of Diversity (online). http://eige.europa.eu/rdc/search?t=diversity\&op=Search, accessed February 20, 2018.

European Commission (2017). 2017 Report on Equality between Women and Men in the European Union. Belgium: UE.

Fonseca, L., Araújo, H. C., Santos, S. A. (2012). Sexualities, teenage pregnancy and educational life histories in Portugal: experiencing sexual citizenship? Gender and Education, 24(6), 647-664.

Fonseca, L., Santos, S.A. (Orgs.) (2015b). Sexualidades, Gravidez e Juventude: Relações sociais e educativas. Porto: Afrontamento.

FRA (2013). European Union lesbian, gay, bisexual and transgender survey. Luxemburg: Publications Office of the European Union.

FRA (2014). Being Trans in the EU. Luxemburg: Publications Office of the European Union. DOI:10.2811/8446.

Jacquot, S. (2016). European Union Gender Equality Policies Since 1957. Encyclopédie pour une histoire nouvelle de l'Europe (online). http://ehne. fr/en/node/1125, accessed April 28, 2018.

Kuhar, R., Paternotte, D. (2017). Anti-Gender Campaigns in Europe Mobilizing against Equality. London: Rowman \& Littlefield International.

Lister, R. (2004). Citizenship and gender. In K. Nash, A. Scott (eds.), The Blackwell companion to political sociology (pp. 323-333). Oxford: The Blackwell Publishing.

Lombardo, E., Verlo0, M. (2009), Institutionalizing Intersectionality in the European Union? International Feminist Journal of Politics, 11(4), 478-495.

OMA Observatorio das Mulheres assassinadas (2017). União de Mulheres Alternativa e Resposta (online). http://www.umarfeminismos.org/images/stories/oma/2017/0MA_ Relat\%C3\%B3rio_Preliminar_20_de_Novembro_de_2017.pdf, accessed October 31, 2018.
Ortbals, C. D. (2008). Subnational politics in Spain: New avenues for feminist policymaking and activism. Politics and Gender, 4(1), 93-119.

Parker, R., Wellings, K., Lazarus, J. V. (2009). Sexuality education in Europe: an overview of current policies. Sex Education, 9(3), 227-242.

Perry, L. B. (2009). Conceptualizing Education Policy in Democratic Societies. Educational Policy, 23(3), 423-450.

Plummer, K. (2003). Intimate citizenship - private decisions and public dialogues. Seattle and London: University of Washington Press.

Regional Ministry of Education (2005). I Plan on Equality between Men and Women. Seville: Junta de Andalucía (online). http://www.juntadeandalucia.es/educacion/webportal/abacoportlet/content/47f2db05-7777-488b-90b9f35e30850766, accessed June 28, 2006.

Richardson, D. (2001). Extending citizenship: cultural citizenship and sexuality. In N. Stevenson (ed.), Culture and citizenship (pp. 153-166). London: Sage.

Richardson, D., Monro, S. (2012). Sexuality, equality and diversity. New York: Palgrave Macmillan.

Santos, S. A. (2015). School-based sex education under the spotlight of sexual and intimate citizenship: a focus on Portugal and England. Phd Thesis. Porto, Portugal: FPCEUP.

Santos, S. A. (2018). La ciudadanía sexual e íntima como espacio para el reconocimiento de la igualdad sexual y de género en la educación sexual. In M. Venegas, P. Chacon-Gordilho, A. Fernández (eds.), De la igualdad de género a la igualdad sexual y de género (pp. 185-204). Madrid: Dykinson.

Santos, S., Fonseca, L. (2013). Olhares educativos sobre saúde sexual: jovens confrontam direitos sexuais e íntimos. In C. Nogueira, S. Magalhães (orgs.). Género e Saúde. Novas (in)visibilidades. APEM e Afrontamento.

Santos, S. A., Araújo, H. C., Fonseca, L. (2012). Sex education and the views of young people on sex and gender in Portuguese schools. Educação, Sociedade and Culturas, 35, 29-44.

Subirats, M., Pérez, E. Canales, A.F. (2013). Género y Educación. In C. Díaz, S. Dema, Sociología y género (pp. 201-252). Madrid: Tecnos.

Venegas, M. (2011). El modelo actual de educación afectivosexual en España. El caso de Andalu- 
cía. Revista Iberoamericana de Educación / Revista Ibero-americana de Educação, 5(3), 1-10.

Venegas, M. (2013a). Sex and relationships education and gender equality: recent experiences from Andalusia (Spain), Sexuality Education: Sexuality, Society and Learning, 13(5), 573-584. https:// doi.org/10.1080/14681811.2013.778823

Venegas, M. (2013b). La educación afectivo-sexual en el marco de la educación para la ciudadanía democrática y los derechos humanos. RASE. Revista de la Asociación de Sociología de la Educación, 6(3), 408-425.

Venegas, M. (2013c). Amor, sexualidad y adolescencia. Sociología de las relaciones afectivosexuales. Granada: Comares.

Venegas, M. (2018a). Introducción. De la igualdad de género, a la igualdad sexual y de género. In M. Venegas, P. Chacón-Gordillo, A. Fernández-Castillo (eds.). De la igualdad de género a la igualdad sexual y de género (pp. 11-25). Madrid: Dykinson.

Venegas, M. (2018b). El romance adolescente. Un análisis sociológico de la política afectivosexual en la adolescencia. Papers. Revista de Sociología, 103(2), 255-279. D0l: http://dx.doi. org/10.5565/rev/papers.2213.

Venegas, M., Villar-Aguilés, A. (2018). De las políticas de igualdad entre mujeres y hombres, a las políticas de igualdad en la diversidad de género en educación. Una aproximación comparada entre los casos andaluces y valenciano. Paper presented at the Midterm Meeting of the Spanish Committee of Sociology of Gender. Valencia, España: FES.

Venegas, P., Chacón-Gordillo, A., Fernández-CastiIlo (eds.) (2018). De la igualdad de género a la igualdad sexual y de género. Madrid: Dykinson.

Verloo, M. (2006). Multiple Inequalities, Intersectionality and the European Union. European Journal of Women's Studies, 13(3): 211-228.

Villar-Aguilés, A. (2018). Coeducación, apuesta por la libertad, reseña del libro de Marina Subirats (2017). Revista de la Asociación de Sociología de la Educación, 11(1), 186-188.

Weeks, J. (1998). Sexuality. London: Routledge.

WHO (2010). Standards for Sexuality Education in Europe. Cologne: Federal Centre for Health Education.

World Health Organization [WHO] (2010). Standards for Sexuality Education in Europe. Cologne: Re- gional Office for Europe and Federal Centre for Health Education.

Young, I. (1997). Intersecting voices. Dilemmas of gender, political philosophy and policy. Princeton: Princeton University Press.

\section{BIOGRAPHICAL NOTES}

Mar Venegas is Senior Lecturer at the Department of Sociology, University of Granada. She has a European Ph.D. (2009) on Sociology and the Postgraduate title of Expert on Gender and Equal Opportunities, both by the University of Granada. She teaches Sociology of Education at the Faculty of Education Sciences. Her research main interests in Sociology are Education, Gender and Sexuality, Youth and Diversity. She is the current Assistant Director of the Department of Sociology and Vice-Director of the Revista de Sociología de la Educación-RASE.

Alícia Villar-Aguilés is a Lecturer and researcher at the Department of Sociology and Social Anthropology of the University of Valencia. Her research lines focus on the sociological analysis of society and education, specifically on the study of educational indicators, educational trajectories, decisions and transitions and education and gender, coeducation and university equality policies. Recently, she has received a sociological essay award for a work on sexual violence. She is Editor in Chief of the Revista de Sociología de la Educación-RASE.

Sofia Almeida Santos is a research fellow at the Centre for Research and Intervention in Education (CIIE) of the Faculty of Psychology and Education Sciences of the University of Porto, Portugal. She holds an European Ph.D (2015) and a Master (2009) in Education in her areas of interest: citizenship, gender, sexual studies and sociology of education. She has actively collaborated in several national and international research projects, giving lectures, engaged in international mobility with European universities and published in these fields. She has been acting as an expert for both national and international public bodies and programmes such as the Council of Europe, Portuguese Directorate General for Education, Directorate Regional for Education of Azores, etc. 
